\title{
Bioenergy production and environmental impacts
}

\author{
Yiping Wu ${ }^{1 *} \mathbb{0}$, Fubo Zhao', Shuguang Liu², Lijing Wang ${ }^{1}$, Linjing Qiu', Georgii Alexandrov³ \\ and Vinayakam Jothiprakash ${ }^{4}$
}

\begin{abstract}
Compared with the conventional fossil fuel, bioenergy has obvious advantages due to its renewability and large quantity, and thus plays a crucial role in helping defend the energy security. However, the bioenergy development may potentially cause serious environmental alterations, which remain unclear. The study summarizes the environmental impacts of bioenergy production based on the compilation and published data. Our analysis shows that more and more attention is being paid to the environmental protection as the development of bioenergy, and among the influencing terms of bioenergy production, water issues (i.e., water quantity and quality) gain the greatest concern, whereas the least attention has been given to soil erosion. Although we recognize that the bioenergy production can indeed exert negative effects on the environment in terms of water quantity and quality, greenhouse gas emissions, biodiversity and soil organic carbon, and soil erosion, the adverse impacts varied greatly depending on biomass types, land locations, and management practices. Identifying the reasonable cultivation locations, appropriate bioenergy crop types, and optimal management practices can be beneficial to environment and sustainable development of bioenergy. In this field, Chinese bioenergy production has lagged behind and does not match its rising energy consumption, but it has a great potential of and demand for biomass-based energy especially under its urbanization, in spite of the negative environmental impacts. Therefore, this article is expected to serve as a reference and guideline on what has been done in the bioenergy-oriented countries that might stimulate development of more effective and environmentally sound guidelines for promoting bioenergy production in China and other developing countries as well.
\end{abstract}

Keywords: Bioenergy, Developing countries, Environmental impacts, Management practice

\section{Background}

Energy is the basic requirement of the development in almost every aspect of a society in the world, and it is also needed by the existence of ecosystems, life itself, and human civilizations (Jiang et al. 2014; Ozturk et al. 2017). However, the utilization of conventional energy sources can yield a series of problems. First, the conventional energy (i.e., fossil fuel) is not renewable, and its excessive use will lead to serious energy crisis, which is now a big concern of the world. Second, the utilization of the traditional fossil fuels can also be polluting sources

\footnotetext{
*Correspondence: rocky.ypwu@gmail.com

${ }^{1}$ Department of Earth and Environmental Science, School of Human Settlements and Civil Engineering, Xi'an Jiaotong University, Xi'an 710049, Shaanxi, China

Full list of author information is available at the end of the article
}

that accelerate global warming, such as the increase of carbon dioxide and other greenhouse gases. Third, the emitted nitrogen oxides due to fossil fuel combustion compromise air quality and do harms in human health (Hoekman et al. 2018). Unfortunately, the world energy consumption depends heavily (80\%) upon fossil fuels and will also increase by more than $50 \%$ in the next 20 years (Ozturk et al. 2017; USEIA 2011). Therefore, bioenergy, the powerful renewable substitution of fossil fuel, has been developing during the past decades especially in North American and Europe, aiming to meet the growth of the world population, safeguard the energy security and mitigate the global warming (Hoekman et al. 2018).

Feedstocks of biofuel production include the grains (e.g., corn kernel and soybean), cellulosic materials such as crop residue (e.g., corn stover), and dedicated energy 
crops (e.g., switchgrass and Miscanthus) (Sang and Zhu 2011; Wu et al. 2015). Thus, bioenergy has attracted much attention and occupied a significant status in the world's energy consumption and in the fight against climate change (Jiang et al. 2012). Although bioenergy accounts for only $14 \%$ of global energy consumption currently (World energy resources 2016, https://www.world energy.org/publications/2016/world-energy-resources2016/), the potential of bioenergy will be tremendous in the near future (Souza et al. 2017). In addition, sustainable bioenergy production can efficiently reduce the risk of energy poverty and contribute to the economic development, especially in developing countries (Schroder et al. 2018; Wicke et al. 2011). Governments around the world are thus trying to promote the bioenergy production as well as seeking appropriate policies or laws to regulate its development. For instance, the US implemented the Energy Independence and Security Act (EISA) in 2007, aiming to increase availability of renewable energy through biofuel production (US Congress 2007). The Malaysia government has introduced the Fifth Fuel Policy in the Eighth Malaysia Plan 2001-2005 to encourage the bioenergy production (Tock et al. 2010). The European Commission has set mandatory targets for an overall share of $20 \%$ renewable energy in EU's transport consumption in 2020 (Van Dam and Junginger 2011). China, as the largest developing country and the second largest economic entity in the world, has a great inherent demand for the bioenergy production in meeting the fast-growing economy, preventing the energy crisis, and meeting the target of greenhouse gas emission reduction. In fact, China has a great potential of bioenergy crop cultivation due to its high profit and environmental benefits in replacing the slope cropland by perennial grass (switchgrass), especially considering the occurring urbanization and accompanied mass migration in China.

Although the bioenergy is projected to be of great importance for energy security, the expansion of bioenergy feedstocks production can potentially cause some adverse environmental alterations. For example, the land conversion from native grass to bioenergy plants or growing bioenergy plants (switchgrass or Miscanthus) on the low-productive land in the Mississippi River Basin can indeed decrease water yield, surface runoff, and streamflow, and increase the evapotranspiration (ET) and nitrogen loss (Hejazi et al. 2015; Kim et al. 2013; Wu and Liu 2012). In addition, the corn-ethanol expansion may cause conflict between food and energy and impact the food security and market; utilizing the corn residue could also induce various implications for soil and water conservation and soil fertility (Hoekman et al. 2018; Warren Raffa et al. 2015). Scientists around the world have paid much attention to the balance between bioenergy production and environmental protection by considering multiple approaches, including the best management practices (BMPs) (Guo et al. 2018; McCalmont et al. 2017a; Wu et al. 2012). Yet the knowledge of the overall environmental effects of bioenergy production remains less clear because of the complexity of the bioenergy production system and the lack of information. The present study is, therefore, to give an overview of the current situation of bioenergy production and its environmental impacts. The first section describes the overall condition of bioenergy production and the related environmental issues. The second section is to describe the environmental issues in detail, and then highlights the potential of bioenergy development in the largest developing country-China.

\section{Bioenergy research overview}

A survey based on publication results related to bioenergy production and its environmental impacts was carried out using the on-line Scopus-Elsevier database (https ://www.scopus.com). Principally, studies containing the key words of the present study (listed in Fig. 1) were examined within the reference period (2000-2017). The papers related to 'bioenergy' kept continuously increasing since the year of 2000; however, the number of bioenergy environmental effects study (e.g., water quantity and quality, GHG emissions, biodiversity and SOC and soil erosion) increased gradually since 2000 with a very slight growth rate (see also the inserted figure in Fig. 1). Of the cumulative publications related to environmental impacts of bioenergy production, the 'water quantity and quality' term ranked first (16\%) in the year of 2017, followed by GHG emissions (6\%), biodiversity and SOC (5\%), and soil erosion (0.8\%), indicating the bioenergy production is more closely related to water resource and water pollution. In addition, the continuous increase of publications related to environmental impacts suggests that more and more attention is being paid to the environmental protection when promoting the bioenergy development.

\section{Environmental issues}

\section{Water quantity and quality}

The effects of bioenergy production on water quantity are mainly through the potential water consumption of bioenergy crops and conversion of land use. For example, the wide expansion in corn ethanol production (first-generation biofuel) in US, encouraged by EISA in 2007, was projected to generate potential water stress at regional and local scales (Gasparatos et al. 2011; Hoekman et al. 2018; Zhou et al. 2015), because the corn requires more water compared to other crops (e.g., wheat and soybean) due to the additional water consume in almost 


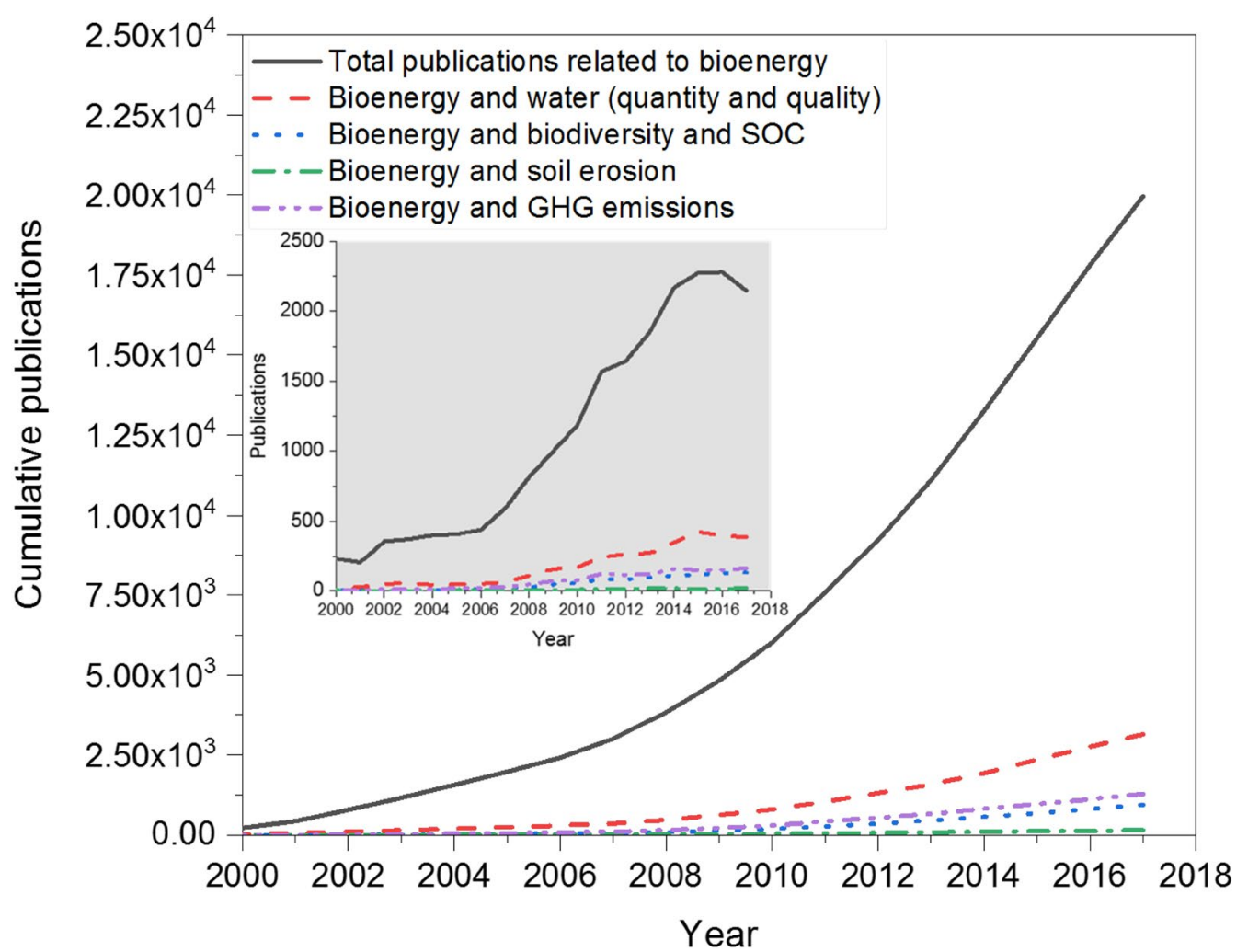

Fig. 1 Publications related to bioenergy production and its environmental effects (water quantity and quality, biodiversity and SOC, soil erosion, and GHG emissions) since the year of 2000. The inserted figure indicates the annual change of publications within the reference period (2000-2017)

every growing stage, especially the joining stage. Particularly, it is estimated that a typical corn-ethanol plant (with a production capacity of 100 million gal/year) uses as much water as a community of 5000 people (Service RF 2009), demonstrating the relatively larger potential water consumption of corn cultivation. In addition, the corn stover removal can also cause increased ET and reductions of water yield at the watershed scale (Cibin et al. 2016; Wu and Liu 2012), though the magnitude of which varied with watershed and harvest rate. The land use conversion, mainly from the native agricultural land or grassland to perennial grasses (e.g., switchgrass and Miscanthus) can also significantly and directly influence the hydrological processes such as ET, surface runoff, water yield, and soil water storage at regional scale. For instance, the modeling results by Kim et al. (2013) illustrated that wide plantation of bioenergy crops will increase the amount of ET, decrease annual surface water and water yield in the Yazoo River Basin of Mississippi River-the major corn production region in US. Similar results were also concluded by Wu and Liu (2012) and Guo et al. (2018), who predicted that the land conversion to bioenergy crops can cause reduction of water resource at the watershed scale.
A significant water quality concern with respect to increasing cultivation of bioenergy crops is nutrient pollution resulting from surface runoff and infiltration to groundwater. The most important polluting source of nutrient pollution is nitrate. As reported by EPA (2011), corn has the highest fertilizer use and low nutrient use efficiency compared to other bioenergy crops. Therefore, increasing the frequency of corn plantation in the corn and soybean rotation system or replacing it with continuous corn would significantly lead to more nitrate to waterways and decrease soil nitrogen content (Wu et al. 2014; Wu and Liu 2012). Nevertheless, there are substantial benefits in land use transition from arable to perennials. Growing perennial grasses reduces $30-40 \%$ of the total nitrogen loss compared with conventional cotton cropping system at the watershed scale (Chen et al. 2017). Guo et al. (2018) simulated that growing bioenergy crops in marginal or erodible areas can not only reduce the streamflow but also the nutrient losses using the scenario analysis with Soil and Water Assessment Tool (SWAT). Additionally, growing perennial grasses needs almost no pesticide, which is helpful for the water quality improvement (Hoekman et al. 2018). Moreover, the above-mentioned water-related concerns can be controlled through 
proper crop species selection and optimal management (e.g., harvest rate, irrigation, appropriate fertilization, and filter strip) (Qin et al. 2018; Wu et al. 2012), indicating the possibility of balance between bioenergy production and water resource protection.

\section{GHG emissions}

Reduction of GHG emissions is one of the most important terms considered in the bioenergy production. Among the GHGs, $\mathrm{CO}_{2}$ and $\mathrm{N}_{2} \mathrm{O}$ are two primary components because of their large quantity and multiapproaches of production (Dunn et al. 2013; Qin et al. 2016). Theoretically, net $\mathrm{CO}_{2}$ emissions resulting from the direct use of biofuels are far less than the utilization of fossil fuel, which has been proven by many studies (Dunn et al. 2013; Fu et al. 2014; Wang et al. 2012). By replacing fossil fuel, Liu et al. (2017) quantified that the maximum potential switchgrass production on marginal land would reduce emissions by 29 million tons $\mathrm{CO}_{2 \text {-eq }}$ year. The model results also suggest that for transportation use in the US, $40-85 \%$ of GHG emissions can be reduced using ethanol relative to gasoline on a per megajoule (MJ) energy basis, though the magnitude of GHGs reduction varied greatly among different feedstocks. Nevertheless, the indirect effects of bioenergy production on $\mathrm{CO}_{2}$ emissions are also important concerns (Dunn et al. 2013; Searchinger et al. 2008), such as the disturbance of $\mathrm{CO}_{2}$ emissions due to the land use transitions (Hill et al. 2006; Sang and Zhu 2011). In a recent review of potential biofuel impacts, Harris et al. (2015) stated that the land transitions from arable to the second generation bioenergy crops can result in slight reduction of $\mathrm{CO}_{2}$ emissions, and the land conversion from native grassland to first generation bioenergy crops and short rotation coppice (SRC) showed a pronounced increase in $\mathrm{CO}_{2}$ emissions. Therefore, it is necessary and significant to consider the appropriate bioenergy crop types and management practices when considering the mitigation of $\mathrm{CO}_{2}$ emissions.

Compared with $\mathrm{CO}_{2}$, the $\mathrm{N}_{2} \mathrm{O}$ is another important greenhouse gas due to its large potential in global warming (298 times that of $\mathrm{CO}_{2}$ ), and agriculture is the largest producer of this gas (Williams et al. 2010). Similar to $\mathrm{CO}_{2}$ emission, the land transitions are the major factors influencing $\mathrm{N}_{2} \mathrm{O}$ emissions. For example, Harris et al. (2015) summarized that the effect of conversion from arable to SRC and perennial grasses was a very small reduction of $-0.2 \mathrm{t} / \mathrm{ha}$ y for $\mathrm{N}_{2} \mathrm{O}$, but the land conversion from grassland to SRC can cause slight increase in $\mathrm{N}_{2} \mathrm{O}$ emissions. In addition, by replacing fossil fuel, Liu et al. (2011) asserted that the use of biomass produced on marginal land for energy could result in a positive environmental impact on national GHG emissions. However, the corn expansion, driven by the demand for ethanol, may also stimulate the $\mathrm{N}_{2} \mathrm{O}$ emission. The corn cultivation need much more fertilizer compared with other crops, especially the nitrogen fertilizer, which is the substrate for soil denitrification process, aggravating $\mathrm{N}_{2} \mathrm{O}$ emission directly. Therefore, the reasonable choice of bioenergy plant type and planting locations is also very important in controlling the $\mathrm{N}_{2} \mathrm{O}$ emission.

\section{Biodiversity and SOC}

Biodiversity is a key indicator related to the food production and ecosystem services (Qin et al. 2018). The impact of biofuel production on biodiversity depends on the initial land use condition, the type of bioenergy production system, and the landscape configuration (Correa et al. 2017; Immerzeel et al. 2014). Land use conversion is the most important factor that affects biological abundance through the direct change of land use condition and production system, which also depends on the plant type and planting locations. For instance, it has been approved that the direct replacement of grassland by several biofuel crops could enhance the local productivity and help maintain the ecosystem functions due to the change of production system (Correa et al. 2017; Sang and Zhu 2011). In addition, many studies emphasized that growing Miscanthus had much less negative impact on biodiversity than annual crops mainly because perennial cultivations provide relatively stable habitats for supporting wild life (Rowe et al. 2009; Werling et al. 2013). In addition, growing energy crops on either low-productive or marginal lands can improve the landscape design, and better management practices can reduce the risk of biodiversity loss at locations, although this requires further studies (Manning et al. 2015; Sang and Zhu 2011).

Soil organic carbon (SOC) is the most important index of soil quality, and high content of SOC benefits the soil water retention, soil biodiversity, and crop productivity. Bioenergy production influences SOC with three major pathways-residue removal, tillage, and land use change. In general, harvesting residues from dead plants that are originally returned to croplands can directly accelerate the SOC loss due to reduced carbon input (Hoekman et al. 2018). Nonetheless, the SOC loss might be controlled, to a certain degree, through an appropriate residue management such as the limited amount of residue removal and additional organic matter inputs (e.g., manure application) (Robertson et al. 2014; Sheehan et al. 2014; Wu et al. 2015). The crop residue is the major source in producing biochar, utilizing the crop residue with an appropriate technique can produce vast biochar with the available crop residues. The application of biochar can help improve the function in the carbon sink of agricultural sector because it can not only aggregate the $\mathrm{SOC}$ but also absorb the inorganic carbon (i.e., $\mathrm{CO}_{2}$ ) 
that exists in the air (Li et al. 2017) and improve the air quality (e.g., mitigation in nitrogen oxides, methane, and PM2.5) (Pourhashem et al. 2017). The second trigger of SOC loss is management practice as well as soil disturbance. For example, Drewniak et al. (2015) simulated the impacts of tillage practices on SOC using a biogeochemical model and found that tillage could always cause SOC loss. Similarly, the field experiments also concluded that the SOC can be highly reduced through the disturbance (e.g., tillage practices) (Cheng 2009; Ouyang et al. 2015; Warren Raffa et al. 2015). In addition, the land conversion is also an important factor causing SOC change. The bioenergy-oriented land use change always refers to conversion from arable to perennial grasses or growing bioenergy crops on marginal croplands, which has positive effects on the SOC sequestration. A recent review also asserted that growing Miscanthus on the arable land will sequester carbon with an accumulation rate ranging from 0.42 to $3.8 \mathrm{Mg}$ C/ha year (McCalmont et al. 2017a). In addition, the biochar application is important to the enhancement of organic carbon in soil because of an organic aggregate with electronegativity that can absorb $\mathrm{CO}_{2}$ from the air and can be beneficial to both the carbon sink of agricultural soil and the protection of air quality (e.g., mitigation in nitrogen oxides, methane, and PM2.5) (Pourhashem et al. 2017). In summary, it is necessary to identify the most suitable areas, plant types, and management measures when considering the biodiversity and carbon sequestration in developing bioenergy.

\section{Soil erosion}

Soil erosion, a very common but severe problem, is also a major point of concern in the bioenergy production, because erosion diminishes soil quality and thereby reduces the productivity of natural and agricultural ecosystems. The soil erosion is also triggered in three main pathways - the corn acreage expansion, residue removal, and land use change. The corn acreage expansion due to the rising demand for ethanol could have serious adverse consequences in soil retention due to its relatively looser planting space. It was estimated that the benefits of conservation measures on soil retention would be diminished further if increased corn cropping occurred on these lands, and cultivating the existing corn crops with appropriate tillage practices would also reduce soil erosion (Hoekman et al. 2018). The crop residue left on the soil surface can buffer wind and water erosive forces (Blanco-Canqui and Wortmann 2017), thus harvesting crop residue can increase the erosion risk due to the less physical protection of soil surface (EPA 2011; Lal 2005), leading to both nutrient and SOC losses. However, according to Cibin et al. (2016), soil erosion induced by high-rate residue removal may be mitigated by appropriate management options, such as the direct input of organic matter and other protecting measures. Additionally, land use conversion might exacerbate erosion or protect soil from erosion. For instance, conversion from forest to perennial bioenergy crops could increases the risk of soil and water loss (Liu et al. 2012), whereas the conversion from the grain crops to perennial grasses may generate positive effects on the soil and water retention because of the erect and ridged stems with sods that are generated by perennials (Cooney et al. 2017). In addition, the perennial grass, especially the switchgrass, could reduce the sediment yield in streamflow and soil erosion and increase the water use and infiltration regardless the climate conditions in the loess gully areas of the Chinese Loess Plateau, indicating the advantage in soil and water conservation of perennials compared to the traditional crops in such regions (Brown et al. 2000; Cooney et al. 2017). Therefore, growing perennial grasses especially in erosion prone areas or slope arable land has a greater potential than corn ethanol production.

\section{Life cycle environmental impact assessment of bioenergy production}

Life cycle assessment (LCA) is a widely used method for quantifying environmental impacts associated with all stages of a product's life from cradle to grave (that is, from raw material extraction through processing, distribution, use, and end-of-life) (Pennington et al. 2004). The LCA has been extensively applied to analyze the pros and cons towards the surrounding environment of bioenergy production in different regions of the world (Boschiero et al. 2016; Cherubini and Stromman 2011; Dias et al. 2017; Homagain et al.et al. 2015), especially in the field of GHG savings and SOC sequestration. Fazio and Monti (2011) evaluated the cradle-to-grave environmental impacts of perennial energy crops cultivation, and they hold that considerable amount of GHG emissions, up to $5 \mathrm{Mg} / \mathrm{ha}$ of fossil-C, could be reduced with the cultivation of perennial crops. In addition, the perennial grasses could be beneficial to the reduction of $\mathrm{N}_{2} \mathrm{O}$ emission (about 40-50\% less emissions compared to fossil fuels). The LCA results obtained by Schmidt et al. (2015) also indicate that the cultivation of perennial grasses on marginal land and their use for heat and power generation can achieve substantial greenhouse gas savings, ranging up to $13 \mathrm{t} \mathrm{CO}_{2}$ eq. / (ha year) with Miscanthus, in spite of the negative environmental impacts. According to Escobar et al. (2017), the switchgrass cultivation in the Mediterranean region of Spain, aiming to generate electricity power, could significantly decrease the GHG emissions. Qin et al. (2018) stated that substituting fossil fuels with biofuels could also significantly reduce the air pollution (e.g., particulate matter) in China. Moreover, LCA studies 
have also demonstrated the environmental benefits of agro-residue based bioenergy production (Guerrero and Muñoz 2018; Soam et al. 2017; Tonini et al. 2016). Soam et al. (2017) reported that the electricity production from rice straw produced a higher GHGs emission reduction than the traditional way in India. Tonini et al. (2016) reported that biofuel production from the agricultural residues without involving land use change is a promising emission reduction option from the perspective of life cycle. According to Parajuli et al. (2017), cultivating willow and alfalfa as feedstocks for bioenergy can potentially sequestrate more soil organic carbon and thus lead to a lower carbon footprint. The bioenergy crops cultivation (e.g., Miscanthus) has also been regarded as the effective $\mathrm{CO}_{2}$ sink in UK (McCalmont et al. 2017b), indicating the bioenergy production can be a good choice for capturing more carbon in soil. Overall, based on the above discussion, it can be concluded that bioenergy production can be beneficial to both the mitigation of GHG emission and the SOC sequestration. However, limited reports have been conducted on the other environmental issues based on LCA, such as the water depletion and water quality dynamics during the bioenergy crops' life cycle, because the impacts of bioenergy production on such problems vary greatly among biomass types, land sources, and management practices. The future study should extend to more environmental fields using LCA to quantify the environmental cost in bioenergy development.

\section{China's bioenergy potential and environmental impacts}

With one-fifth of the world's population, China is a fastgrowing economic entity accompanied with increasing energy consumption. Developing bioenergy to displace the conventional fossil fuels for reducing carbon emission and protecting our earth village is great of interest and urgency for China and the world as well. In fact, China's potential of bioenergy production is tremendous. China is one of the largest agricultural countries in the world and has approximately 130 million hectares (Mha) farmland, yielding above 600 million tons (Mt) of crop residues, which is the potential biofuel production feedstock (Jiang et al. 2012; Liu et al.et al. 2012; Sang and Zhu 2011). However, as reported by Sang and Zhu (2011), about $200 \mathrm{Mt}$ of crop residues were combusted at low conversion efficiency and above $100 \mathrm{Mt}$ were burned directly in field, releasing more carbon that are already stored in the system and absolutely causing air pollution. If more crop residues are utilized at a higher efficiency, the magnitude of bioenergy would be larger and the energy consumption would be more reasonable. In addition, the application of biochar produced using residue is important to the enhancement of organic carbon in soil because of an organic aggregate with electronegativity that can absorb $\mathrm{CO}_{2}$ from the air and can be beneficial to both the carbon sink of agricultural soil and the protection of air quality (Pourhashem et al. 2017). Therefore, it is significant to develop more efficient techniques to make full use of the crop residues. China has a huge area of low-productive or slope arable lands that can be utilized for growing bioenergy crops (Fu et al. 2014; Lu et al. 2014; Sang and Zhu 2011). It was estimated by Sang and Zhu (2011) that China has above 100 Mha of land potentially suitable for growing bioenergy crops, and the crops can achieve 1 billion tons of biofuel feedstock if converting all the degraded land to Miscanthus. In addition, China possesses rich plants species as well as genetic resource, especially for Miscanthus, thus it has a great potential to derive appropriate bioenergy crop types for balancing the bioenergy production and environmental protection. The lag in bioenergy development and declining share of renewable energy consumption (Table 1) as contrasted with the US and European Union efforts calls for more efficient policies on promoting the bioenergy production to safeguard energy security and climate change mitigation. Scientific research should be aimed to gain more knowledge and derive optimal management for guiding bioenergy development and environmental protection in China and other developing countries as well.

The significant concerns of bioenergy production in China are mainly the agricultural production and the water resource problem. It has to be acknowledged that China has been feeding about $22 \%$ of the world's population with just $7 \%$ of the globe's agricultural land, and ensuring the food production is the eternal topic. According to Sang and Zhu (2011), China has little cropland that can be converted for bioenergy crops cultivation, thus, the food production should be the national priority when we planning the bioenergy production (that is, the bioenergy development cannot compromise

Table 1 Renewable energy consumption (\% of the total final energy consumption) Source: World Bank, Sustainable Energy for All database (https://data.worldbank.org/ indicator/EG.FEC.RNEW.ZS)

\begin{tabular}{lrrc}
\hline Country & $\mathbf{1 9 9 0}$ & $\mathbf{2 0 1 4}$ & Increase/decrease \\
\hline European Union & 6.13 & 16.05 & 9.92 \\
United States & 4.18 & 8.91 & 4.73 \\
South Africa & 16.63 & 16.59 & -0.04 \\
Russian Federation & 3.75 & 3.46 & -0.29 \\
Brazil & 49.86 & 41.81 & -8.05 \\
China & 34.08 & 17.10 & -16.98 \\
India & 58.65 & 36.54 & -22.11 \\
\hline
\end{tabular}


food production). Conversely, China has large areas of marginal lands, which are always located in the arid and semi-arid region and suffered from severe water deficit and are not suitable for farming. It has been previously suggested that the marginal lands hold a great potential for the production of perennial herbaceous energy crops (Liu et al. 2012; McCalmont et al. 2017a; Sang and Zhu 2011). However, the biofuel is certainly to have a high water footprint on the basis of per unit energy production. As described above, growing the bioenergy crops (e.g., switchgrass or Miscanthus) will increase the amount of ET, leading to the reduction of water resource. According to Yaeger et al. (2013) and Liu et al. (2012), there may be potentially large negative impacts on the total water resource where the bioenergy crops plantation size is mismatched to water resource carrying capacity. This may exacerbate the water deficit of the marginal land and aggravate the water scarcity of China. Therefore, the appropriate size and selection of planting location should be taken into account seriously when planning the bioenergy crops cultivation in China. Clearly, we need to deeply understand how the large-scale production of bioenergy could affect the agriculture, water availability and quality, soil quality, and other environmental issues when developing bioenergy in China and other parts of the world.

\section{Summary}

Bioenergy has obvious advantages compared to the traditional fossil fuel, because of their large quantity and renewability, and thus plays a crucial role in defending the energy security of the globe. However, it is significant to take the resource and environmental cost into account when implementing the bioenergy production. The study summarizes the environmental impacts of bioenergy development based on published results, and our analysis indicated that bioenergy-oriented environmental studies were not given as much attention as bioenergy itself in spite of their increasing trend. Among the influencing terms of bioenergy production, water issues (i.e., water quantity and quality) gain the greatest concern, whereas the least attention has been paid to the soil erosion. Although the bioenergy production can indeed exert negative effects on the surrounding environments, consisting of water quantity and quality, GHG emissions, biodiversity and SOC, and soil erosion, the adverse impacts on environment varied greatly among plant types, land sources, and management practices. Identifying the appropriate cultivation areas, suitable bioenergy crop types, and optimal management practices can be beneficial to both bioenergy production and environment. China has a large potential of bioenergy production, but Chinese bioenergy production has lagged behind and does not match its rising energy consumption. The future research should learn from the leading countries in this field, gain more knowledge, and derive optimal decision support for guiding the development of bioenergy in China and other developing countries. Overall, this study could give a big picture on and be informative in planning the bioenergy development as well as environmental protection.

\section{Abbreviations \\ GHG: greenhouse gas; SOC: soil organic carbon; ET: evapotranspiration; EU: European union; EISA: energy independence and security act; EPA: United States environmental protection agency; BMP: best management practice; SWAT: soil and water assessment tool; SRC: short rotation coppice; Mha: mil- lion hectares; Mt: million tons. \\ Authors' contributions \\ YW and FZ contributed to study design, data collection and interpretation, manuscript preparation, and literature search. All other authors contribute to data analysis. All authors read and approved the final manuscript. \\ Author details \\ ${ }^{1}$ Department of Earth and Environmental Science, School of Human Settle- ments and Civil Engineering, Xi'an Jiaotong University, Xi'an 710049, Shaanxi, China. ${ }^{2}$ National Engineering Laboratory for Applied Technology of Forestry \& Ecology in South China, Central South University of Forestry and Technology, Changsha 410004, Hunan, China. ${ }^{3}$ A.M. Obukhov Institute of Atmospheric Physics, Russian Academy of Sciences, Moscow 119017, Russia. ${ }^{4}$ Department of Civil Engineering, Indian Institute of Technology Bombay, Mumbai 400076, India.}

\section{Acknowledgements}

This study was funded by the National Thousand Youth Talent Program of China (122990901606), the Hundred Youth Talent Program of Shaanxi Province, the Young Talent Support Plan of Xi'an Jiaotong University.

\section{Competing interests}

The authors declare that they have no competing interests.

\section{Availability of data and materials}

The data supporting our analyses can be accessed publicly from the link provided in the paper, and we will also share the data soon after the manuscript is published.

\section{Consent for publication}

Not applicable.

Ethics approval and consent to participate Not applicable.

\section{Funding}

The study was funded by the National Thousand Youth Talent Program of China (122990901606), the Hundred Youth Talent Program of Shaanxi Province, the Young Talent Support Plan of Xi'an Jiaotong University.

\section{Publisher's Note}

Springer Nature remains neutral with regard to jurisdictional claims in published maps and institutional affiliations.

Received: 23 January 2018 Accepted: 18 May 2018

Published online: 24 May 2018 


\section{References}

Blanco-Canqui H, Wortmann C (2017) Crop residue removal and soil erosion by wind. J Soil Water Conserv 72(5):97A-104A

Boschiero M, Cherubini F, Nati C, Zerbe S (2016) Life cycle assessment of bioenergy production from orchards woody residues in northern Italy. $J$ Clean Prod 112:2569-2580

Brown RA, Rosenberg NJ, Hays CJ, Easterlling WE, Mearns LO (2000) Potential production and environmental effects of switchgrass and traditional crops under current and greenhouse-altered climate in the central United States: a simulation study. Agr Ecosyst Environ 78:31-47

Chen Y, Ale S, Rajan N, Srinivasan R (2017) Modeling the effects of land use change from cotton (Gossypium hirsutum L.) to perennial bioenergy grasses on watershed hydrology and water quality under changing climate. Agric Water Manag 192:198-208

Cheng W (2009) Rhizosphere priming effect: its functional relationships with microbial turnover, evapotranspiration, and $\mathrm{C}-\mathrm{N}$ budgets. Soil Biol Biochem 41(9):1795-1801

Cherubini F, Stromman AH (2011) Life cycle assessment of bioenergy systems: state of the art and future challenges. Bioresour Technol 102(2):437-451

Cibin R, Trybula E, Chaubey I, Brouder SM, Volenec JJ (2016) Watershed-scale impacts of bioenergy crops on hydrology and water quality using improved SWAT model. GCB Bioenergy 8(4):837-848

Cooney D, Kim H, Quinn L, Lee M-S, Guo J, Chen S-I Xu, B-c Lee DK (2017) Switchgrass as a bioenergy crop in the Loess Plateau, China: potential lignocellulosic feedstock production and environmental conservation. $J$ Integr Agr 16(6):1211-1226

Correa DF, Beyer HL, Possingham HP, Thomas-Hall SR, Schenk PM (2017) Biodiversity impacts of bioenergy production: microalgae vs. first generation biofuels. Renew Sustain Energy Rev 74:1131-1146

Dias GM, Ayer NW, Kariyapperuma K, Thevathasan N, Gordon A, Sidders D, Johannesson GH (2017) Life cycle assessment of thermal energy production from short-rotation willow biomass in southern Ontario, Canada. Appl Energy 204:343-352

Drewniak BA, Mishra U, Song J, Prell J, Kotamarthi VR (2015) Modeling the impact of agricultural land use and management on US carbon budgets. Biogeosciences 12(7):2119-2129

Dunn JB, Mueller S, H-y Kwon, Wang MQ (2013) Land-use change and greenhouse gas emissions from corn and cellulosic ethanol. Biotechnol Biofuels 6:51

EPA (2011) Biofuels and the environment: first triennial report to congress. National Center for Environmental Assessment EPA:2011

Escobar N, Ramírez-Sanz C, Chueca P, Moltó E, Sanjuán N (2017) Multiyear life cycle assessment of switchgrass (Panicum virgatum L.) production in the Mediterranean region of Spain: a comparative case study. Biomass Bioenergy 107:74-85

Fazio S, Monti A (2011) Life cycle assessment of different bioenergy production systems including perennial and annual crops. Biomass Bioenergy 35(12):4868-4878

Fu J, Jiang D, Huang Y, Zhuang D, Ji W (2014) Evaluating the marginal land resources suitable for developing bioenergy in Asia. Adv Meteorol 2014:1-9

Gasparatos A, Stromberg P, Takeuchi K (2011) Biofuels, ecosystem services and human wellbeing: putting biofuels in the ecosystem services narrative. Agr Ecosyst Environ 142(3-4):111-128

Guerrero AB, Muñoz E (2018) Life cycle assessment of second generation ethanol derived from banana agricultural waste: environmental impacts and energy balance. J Clean Prod 174:710-717

Guo T, Cibin R, Chaubey I, Gitau M, Arnold JG, Srinivasan R, Kiniry JR, Engel BA (2018) Evaluation of bioenergy crop growth and the impacts of bioenergy crops on streamflow, tile drain flow and nutrient losses in an extensively tile-drained watershed using SWAT. Sci Total Environ 613-614:724-735

Harris ZM, Spake R, Taylor G (2015) Land use change to bioenergy: a metaanalysis of soil carbon and GHG emissions. Biomass Bioenergy 82:27-39

Hejazi MI, Voisin N, Liu L, Bramer LM, Fortin DC, Hathaway JE, Huang M, Kyle P, Leung LR, Li HY, Liu Y, Patel PL, Pulsipher TC, Rice JS, Tesfa TK, Vernon CR, Zhou Y (2015) 21st century United States emissions mitigation could increase water stress more than the climate change it is mitigating. PNAS 112(34):10635-10640
Hill J, Nelson E, Tilman D, Polasky S, Tiffany D (2006) Environmental, economic, and energetic costs and benefits of biodiesel and ethanol biofuels. PNAS 103(30):11206-11210

Hoekman SK, Broch A, Liu X (2018) Environmental implications of higher ethanol production and use in the US: a literature review. Part I-impacts on water, soil, and air quality. Renew Sustain Energy Rev 81:3140-3158

Homagain K, Shahi C, Luckai N, Sharma M (2015) Life cycle environmental impact assessment of biochar-based bioenergy production and utilization in Northwestern Ontario, Canada. J Forestry Res 26(4):799-809

Immerzeel DJ, Verweij PA, van der Hilst F, Faaij APC (2014) Biodiversity impacts of bioenergy crop production: a state-of-the-art review. GCB Bioenergy 6(3):183-209

Jiang D, Zhuang D, Fu J, Huang Y, Wen K (2012) Bioenergy potential from crop residues in China: availability and distribution. Renew Sustain Energy Rev 16(3):1377-1382

Jiang D, Hao M, Fu J, Zhuang D, Huang Y (2014) Spatial-temporal variation of marginal land suitable for energy plants from 1990 to 2010 in China. Sci Rep 4:5816

Kim HK, Parajuli PB, Filip To SD (2013) Assessing impacts of bioenergy crops and climate change on hydrometeorology in the Yazoo River Basin, Mississippi. Agric For Meteorol 169:61-73

Lal R (2005) World crop residues production and implications of its use as a biofuel. Environ Int 31(4):575-584

Li W, Dang Q, Brown RC, Laird D, Wright MM (2017) The impacts of biomass properties on pyrolysis yields, economic and environmental performance of the pyrolysis-bioenergy-biochar platform to carbon negative energy. Bioresour Technol 241:959-968

Liu T, McConkey BG, Ma Z, Liu Z, Li X, Cheng L (2011) Strengths, weaknesses, opportunities and threats analysis of bioenergy production on marginal land. Energy Procedia 5:2378-2386

Liu W, Yan J, Li J, Sang T (2012) Yield potential of Miscanthus energy crops in the Loess Plateau of China. GCB Bioenergy 4(5):545-554

Liu T, Huffman T, Kulshreshtha S, McConkey B, Du Y, Green M, Liu J, Shang J, Geng X (2017) Bioenergy production on marginal land in Canada: potential, economic feasibility, and greenhouse gas emissions impacts. Appl Energy 205:477-485

Lu L, Jiang D, Fu J, Zhuang D, Huang Y, Hao M (2014) Evaluating energy benefit of Pistacia chinensis based biodiesel in China. Renew Sustain Energy Rev 35:258-264

Manning P, Taylor G, Hanley ME (2015) Bioenergy, food production and biodiversity-an unlikely alliance? GCB Bioenergy 7(4):570-576

McCalmont JP, Hastings A, McNamara NP, Richter GM, Robson P, Donnison IS, Clifton-Brown J (2017a) Environmental costs and benefits of growing Miscanthus for bioenergy in the UK. GCB Bioenergy 9(3):489-507

McCalmont JP, McNamara NP, Donnison IS, Farrar K, Clifton-Brown J (2017b) An interyear comparison of $\mathrm{CO}_{2}$ flux and carbon budget at a commercialscale land-use transition from semi-improved grassland to Miscanthus $x$ giganteus. GCB Bioenergy 9:229-245

Ouyang W, Lai X, Li X, Liu H, Lin C, Hao F (2015) Soil respiration and carbon loss relationship with temperature and land use conversion in freeze-thaw agricultural area. Sci Total Environ 533:215-222

Ozturk M, Saba N, Altay V, Iqbal R, Hakeem KR, Jawaid M, Ibrahim FH (2017) Biomass and bioenergy: an overview of the development potential in Turkey and Malaysia. Renew Sustain Energy Rev 79:1285-1302

Parajuli R, Knudsen MT, Djomo SN, Corona A, Birkved M, Dalgaard T (2017) Environmental life cycle assessment of producing willow, alfalfa and straw from spring barley as feedstocks for bioenergy or biorefinery systems. Sci Total Environ 586:226-240

Pennington DW, Potting J, Finnveden G, Lindeijer E, Jolliet O, Rydberg T, Rebitzer G (2004) Life cycle assessment part 2: current impact assessment practice. Environ Int 30(5):721-739

Pourhashem G, Rasool QZ, Zhang R, Medlock KB, Cohan DS, Masiello CA (2017) Valuing the air quality effects of biochar reductions on soil $\mathrm{NO}$ emissions. Environ Sci Technol 51(17):9856-9863

Qin Z, Dunn JB, Kwon H, Mueller S, Wander MM (2016) Influence of spatially dependent, modeled soil carbon emission factors on life-cycle greenhouse gas emissions of corn and cellulosic ethanol. GCB Bioenergy $8(6): 1136-1149$

Qin Z, Zhuang Q, Cai X, He Y, Huang Y, Jiang D, Lin E, Liu Y, Tang Y, Wang MQ (2018) Biomass and biofuels in China: toward bioenergy resource 
potentials and their impacts on the environment. Renew Sustain Energy Rev 82:2387-2400

Robertson GP, Grace PR, Izaurralde RC, Parton WP, Zhang X (2014) $\mathrm{CO}_{2}$ emissions from crop residue-derived biofuels. Nat Clim Change 4(11):933-934

Rowe RL, Street NR, Taylor G (2009) Identifying potential environmental impacts of large-scale deployment of dedicated bioenergy crops in the UK. Renew Sustain Energy Rev 13(1):271-290

Sang T, Zhu W (2011) China's bioenergy potential. GCB Bioenergy 3(2):79-90

Schmidt T, Fernando AL, Monti A, Rettenmaier N (2015) Life cycle assessment of bioenergy and bio-based products from perennial grasses cultivated on marginal land in the Mediterranean region. Bioenergy Res 8(4):1548-1561

Schroder P, Beckers B, Daniels S, Gnadinger F, Maestri E, Marmiroli N, Mench M, Millan R, Obermeier MM, Oustriere N, Persson T, Poschenrieder C, Rineau F, Rutkowska B, Schmid T, Szulc W, Witters N, Saebo A (2018) Intensify production, transform biomass to energy and novel goods and protect soils in Europe-a vision how to mobilize marginal lands. Sci Total Environ 616-617:1101-1123

Searchinger T, Heimlich R, Houghton RA, Dong F, Elobeid A, Fabiosa J, Tokgoz S, Hayes D, Yu T-H (2008) Use of US croplands for biofuels increases greenhouse gases through emissions from land-use change. Science 319:1238-1240

Service RF (2009) Another biofuels drawback: the demand for irrigation. Science 326:517-518

Sheehan JJ, Adler PR, Del Grosso SJ, Easter M, Parton W, Paustian K, Williams $\mathrm{S}$ (2014) $\mathrm{CO}_{2}$ emissions from crop residue-derived biofuels. Nat Clim Change 4(11):932-933

Soam S, Borjesson P, Sharma PK, Gupta RP, Tuli DK, Kumar R (2017) Life cycle assessment of rice straw utilization practices in India. Bioresour Technol 228:89-98

Souza GM, Ballester MVR, de Brito Cruz CH, Chum H, Dale B, Dale VH, Fernandes ECM, Foust T, Karp A, Lynd L, Maciel Filho R, Milanez A, Nigro F, Osseweijer P, Verdade LM, Victoria RL, Van der Wielen $L$ (2017) The role of bioenergy in a climate-changing world. Environ Dev 23:57-64

Tock JY, Lai CL, Lee KT, Tan KT, Bhatia S (2010) Banana biomass as potential renewable energy resource: a Malaysian case study. Renew Sustain Energy Rev 14(2):798-805

Tonini D, Hamelin L, Alvarado-Morales M, Astrup TF (2016) GHG emission factors for bioelectricity, biomethane, and bioethanol quantified for 24 biomass substrates with consequential life-cycle assessment. Bioresour Technol 208:123-133

US Congress (2007) Energy independence and security act of 2007 (HR 6. 110th Congress. 1st session. December 2007)
USEIA (2011) International energy outlook 2011. US Energy Information Administration, Washington, DC

Van Dam J, Junginger M (2011) Striving to further harmonization of sustainability criteria for bioenergy in Europe: recommendations from a stakeholder questionnaire. Energy Policy 39(7):4051-4066

Wang M, Han J, Dunn JB, Cai H, Elgowainy A (2012) Well-to-wheels energy use and greenhouse gas emissions of ethanol from corn, sugarcane and cellulosic biomass for US use. Environ Res Lett 7(4):045905

Warren Raffa D, Bogdanski A, Tittonell P (2015) How does crop residue removal affect soil organic carbon and yield? A hierarchical analysis of management and environmental factors. Biomass Bioenergy 81:345-355

Werling BP, Dickson TL, Rufus I, Hannah G, Claudio G, Gross KL, Heidi L, Malmstrom CM, Meehan TD, Ruan L, Roberston BA, Roberston GP, Schmidt TM, Schrotenboer AC, Teal TK, Wilson JK, Landis DA (2013) Perennial grasslands enhance biodiversity and multiple ecosystem services in bioenergy landscapes. PNAS 111(4):1652-1657

Wicke B, Smeets E, Watson H, Faaij A (2011) The current bioenergy production potential of semi-arid and arid regions in sub-Saharan Africa. Biomass Bioenergy 35(7):2773-2786

Williams AG, Audsley E, Sandars DL (2010) Environmental burdens of producing bread wheat, oilseed rape and potatoes in England and Wales using simulation and system modelling. Int J Life Cycle Assess 15(8):855-868

Wu Y, Liu S (2012) Impacts of biofuels production alternatives on water quantity and quality in the lowa River Basin. Biomass Bioenergy 36:182-191

Wu Y, Liu S, Li Z (2012) Identifying potential areas for biofuel production and evaluating the environmental effects: a case study of the James River Basin in the Midwestern United States. GCB Bioenergy 4(6):875-888

Wu M, Zhang Z, Y-w Chiu (2014) Life-cycle water quantity and water quality implications of biofuels. Curr Sustain Renew Energy Rep 1(1):3-10

Wu Y, Liu S, Young CJ, Dahal D, Sohl TL, Davis B (2015) Projection of corn production and stover-harvesting impacts on soil organic carbon dynamics in the US Temperate Prairies. Sci Rep 5:10830

Yaeger MA, Sivapalan M, Mclsaac GF, Cai X (2013) Comparative analysis of hydrologic signatures in two agricultural watersheds in east-central Illinois: legacies of the past to inform the future. Hydrol Earth Syst Sci 17(11):4607-4623

Zhou X, Clark CD, Nair SS, Hawkins SA, Lambert DM (2015) Environmental and economic analysis of using SWAT to simulate the effects of switchgrass production on water quality in an impaired watershed. Agric Water Manag 160:1-13

\section{Submit your manuscript to a SpringerOpen ${ }^{\circ}$ journal and benefit from:}

- Convenient online submission

- Rigorous peer review

- Open access: articles freely available online

- High visibility within the field

Retaining the copyright to your article

Submit your next manuscript at springeropen.com 